\title{
Konsep Rezeki Perspektif Wahbah al-Zuhaili Dalam TafsỉR Al-MuniR
}

\author{
Zubairi \\ Jatim \\ STIU Al-Mujtama Pamekasan \\ e-mail: jamis.mr@gmail.com
}

\begin{abstract}
Abstrak: Salah satu hal yang menjadi penyempurna kehidupan setiap manusia adalah terjaminnya rezeki. Sehingga rezeki menjadi tujuan utama manusia untuk dapat mempertahankan hidupnya. Realita yang terjadi saat ini, manusia beranggapan bahwa ukuran rezeki hanya terdapat pada harta kekayaan saja. Namun, rezeki yang sesungguhnya terbagi menjadi dua. Pertama, rezeki yang merupakan kebutuhan jasmaniah seperti, makanan, minuman, pakaian, rumah dan lain-lain. Kedua, rezeki yang menjadi kebutuhan rohaniah seperti, ilmu pengetahuan, kecerdasan, taufik serta hidayah dalam kehidupan. Penelitian ini menggunakn pendekatan kualitatif dengan jenis penelitian pustaka (library research) yang difokuskan pada penelusuran literature-literatur dan bahan pustaka yang berkaitan dengan tema penelitian, kemudian data tersebut dianasilis menggunakan deskriptif analisis. Hasil penelitian terhadap penafsiran Wahbah al-Zuhaili surah Hūd ayat 6, dapat disimpulakan bahwa setiap manusia terjamin kesejahteraan rezekinya, bahkan semua makhluk di muka bumi sekalipun ada rezekinya masing-masing. Lebih lanjut wahbah Zuhaili menegaskan bahwa rezeki akan terjamin apabila manusia mau berusaha dan bekerja sesuai dengan kudrat yang dimilikki manusia dalam menjalani kehiduapan ini.
\end{abstract}

Kata Kunci: Konsep, Rezeki, Perspektif, Wahbah al-Zuhaili

Abstract: One of the enhancers of life for human being is fulfillment of sustenance. So that the sustenances became the main goal of human to survive their life. Reality that occurs when this, humans assume that the size of the provision is only found in the treasures of wealth alone. However, sustenance is actually divided into two. First, the provision that the requirement of physical like, food, drinks, clothing, house and others. Second, the provision which became needs spiritual as, science knowledge, intelligence, guidance in life.

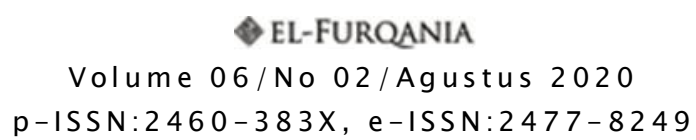


This research used qualitative approach with the type of library research, that is focused on the literary research which the materials relates to the theme of the study, then the data are analyzed by descriptive analysis. The results of research on the interpretation of Wahbah al-Zuhaili surah Hud verse 6, it can be concluded that every human being is guaranteed the welfare of his sustenance, even all creatures on earth even though they have their own sustenance. Further, Wahbah Zuhaili emphasized that sustenance will be guaranteed if humans are willing to try and work in accordance with the human rights in living this life.

Keywords: Concept, blessing, interpretation, Wahbah al-Zuhaili

\section{Prolog}

Rezeki daam Isam merupakan suatu anugerah nikmat yang di karuniakan Allah SWT. kepada seluruh makhluk-Nya untuk keperluan hidupnya, baik yang berupa keperluan jasmani maupun rohani seperti makanan, ilmu dan lain sebagainya. ${ }^{1}$ Salah satu kekuasaan Allah SWT. yaitu memiliki sifat al-Razzāq (maha memberi rezeki) kepada setiap makhluk-Nya. Sehingga seluruh makhluk-Nya akan diberi rezeki masing-masing. Allah SWT. berfirman dalam surah Hūd [11] ayat 6:

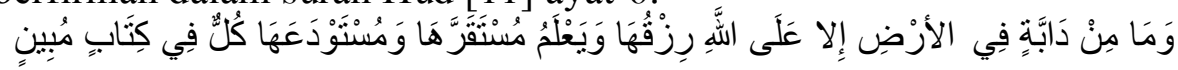

"Dan tidak ada suatu binatang melata pun di bumi melainkan atas Allahlah rezekinya, dan Dia mengetahui tempat berdiamnya dan tempat penyimpanannya. Semuanya tertulis dalam kitab yang nyata". (QS.Hūd [11]: 6) ${ }^{2}$

Kekusaan Allah SWT. dengan mengetahui secara menyeluruh sampai pada sesuatu yang terkecil menunjukkan bahwa nikmat-Nya mencakup semua makhluk. Sehingga bukan hanya orang yang kafir dan munafik saja yang di ketahui keadaannya melainkan semua makhluk-Nya karena tidak ada suatu binatang melata pun di muka bumi ini melainkan atas Allah lah jaminan rezekinya. ${ }^{3}$

${ }^{1}$ Mualimin el-Bansiry, Tuntunan Hidup Kaya dengan Jalan Allah: Sikap dan Perilaku hidup yang Memudahkan Jalan Rezeki Anda, ( Yogyakarta: Luna Publisher, 2009), 8.

${ }^{2}$ Kementerian Agama RI, al-Qur'an dan terjemahnya, (Jakarta: New Cordova, 2012), 222.

${ }^{3}$ M. Quraish shihāb, Tafsir al-Misbāh: Pesan, Kesan, dan Keserasian al-Qur'an, Vol 6 ( Jakarta:Lentera Hati, 2002), 188 
Dalam kajian Islam rezeki merupakan segala sesuatu yang di berikan oleh Allah SWT. yang diperoleh dengan cara yang halal yang tidak terfokus hanya pada makanan saja namun banyak diantara manusia yang belum mengetahui tentang rezeki secara luas. ${ }^{4}$ Rezeki tidak serta merta datang dengan sendirinya melainkan ada usaha yang tidak menutup kemungkinan semua orang dapat berusaha sesuai kemampuan masing-masing. Di samping itu semua, keterkaitan antara tingkat keimanan dan ketakwaan seseorang dalam menjalani hidupnya juga menjadi salah satu sebab seseorang dimudahkan rezekinya sebagaimana dikatakan bahwa semakin tinggi tingkat keimanan dan ketaqwaan seseorang maka niscaya semakin mudah memperoleh rezeki yang tiada disangka-sangka. ${ }^{5}$ Hal ini dijelaskan dalam al-Qur'an Surah al-Ṭalāq [65] ayat 2-3:

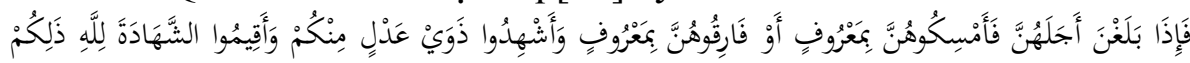

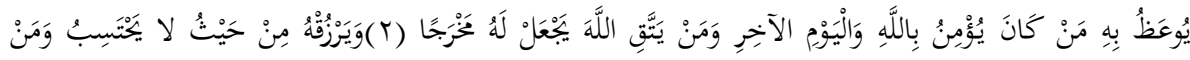

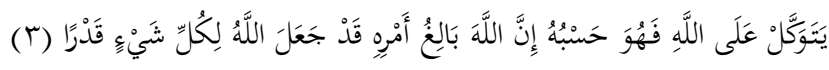

"Barang siapa bertaqwa kepada Allah niscaya Dia akan membukakan jalan keluar baginya, dan Dia memberinya rezeki dari arah yang tidak disangka-sangka". (QS. al-Ṭalāq [65]: 2-3) ${ }^{6}$

Mutawalli al-Sha'rawi menyatakan, rezeki adalah setiap sesuatu yang dapat diambil manfaat oleh pemiliknya serta dapat di manfaatkan oleh orang lain dalam kebaikan tanpa menimbulkan mudarat terhadap keberlangsungan hidup manusia. ${ }^{7}$ Seiring berputarnya waktu maka muncullah problematika yang sering terjadi dikalangan masyarakat justru berbalik arah dari hakikat rezeki yang dikemukakan oleh para ulama dan yang dibahas dalam ajaran agama Islam. Akibat dari keterbatasan manusia, banyak diantara mereka justru berpandangan bahwa uang dan materi adalah satu-satunya rezeki yang diberikan oleh Allah SWT., padahal uang dan materi hanyalah sebagian kecil dari rezeki Allah SWT. Rezeki yang Allah berikan kepada hamba-hamba-Nya sebenarnya tidak terhitung jumlahnya bahkan kehidupan kita merupakan rezeki yang tidak kita

\footnotetext{
${ }^{4}$ Muhammad Muhyiddin, Keajaiban Shodaqoh (Jokjakarta: DIVA pres, 2013) 209.

${ }^{5}$ Ibid, 210

6 Kementerian Agama RI, al-Qur'an dan terjemahnya, (Jakarta: New Cordova, 2012),558.

7 Mualimin el-Bansiry, Tuntunan Hidup Kaya dengan Jalan Allah: Sikap dan Perilaku hidup yang Memudahkan Jalan Rezeki Anda, ( Yogyakarta: Luna Publisher, 2009), 8.
} 
sadari. ${ }^{8}$ Sebagaimana dijelaskan oleh Allah SWT. dalam al-Qur'an Surah al-Nahl[16] ayat 18:

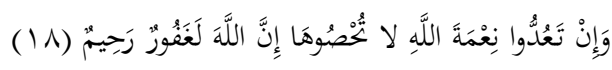

"Dan jika kamu menghitung nikmat Allah, niscaya kamu tidak akan mampu menghitungnya. Sungguh, Allah benar-benar maha pengampun lagi maha penyayang".(QS. al-Nahl [16]:18). ${ }^{9}$

Pada dasarnya penelitian tentang rezeki sudah banyak seperti penelitian Achmad Kurniawan Pasmadi yang berjudul "Konsep Rezeki dalam al-Qur'an", tahun 2015. Penelitian ini membahas tentang rezeki dalam al-Qur'an secara umum dalam artian tanpa perspektif salah satu mufassir. Penelililtian Mahmuddin, "Penafsiran Ayat-ayat Rizq Menurut M. Quraish Shihab Telaah Kajian Tafsir alMisbah",. Penelitian ini ditulis tahun 2009, dengan pembahasa seputar ayat-ayat yang berhubungan dengan rezeki, melalui penjabaran ayat-ayat tentang sumber rezeki dan menjabarkan ayatayat yang berbicara tentang macam-macam rezeki serta cara memperoleh dan penggunaan rezeki.

Berdasarkan latar belakang di atas, maka penulis merasa perlu memberikan pemahaman tentang rezeki dan hal-hal yang berkaitan dengan rezeki, di samping banyaknya umat manusia yang masih kurang faham tentang hakikat dari Rezeki yang sebenarnya. Maka penulis akan mengkaji lebih dalam lagi tentang "konsep rezeki perspektif Wahbah al-Zuhaili dalam Tafsir al-Munir " fokus pada analisa QS. Hud ayat 6", dengan meto deskriptif analitas.

\section{Biografi wahbah al-zuhaili}

Nama lengkapnya adalah Wahbah Bin Musthafa al-Zuhaili, beliau adalah anak dari Musthafa al-Zuhaili, yakni seorang petani yang sederhana dan terkenal dalam keshalihannya. Wahbah al-Zuhaili dilahirkan pada 6 Maret tahun 1932 M/1351 H, bertempat di Dair Atiyah Kecamatan Faifa, Provinsi Damaskus Suriah . ${ }^{10}$ Sedangkan ibunya bernama Hajjah Fatimah Binti Musthafa Sa,adah. Beliau seorang wanita yang memiliki sifat warak dan teguh dalam menjalankan syari'at Islam. Wahbah al-Zuhaili adalah seorang tokoh

\footnotetext{
${ }^{8}$ Insan Nurrohiem, Kaya itu Bonus, (Yogyakarta: Laksana, 2018), 13.

9 Kementerian Agama RI, al-Qur'an dan terjemahnya, (Jakarta: New Cordova, 2012), 269.

${ }^{10}$ Syaiful Amin Ghofur, Profil Para Mufassir al-Qur'an, (Yogyakarta: Pustaka Insan Madani, 2008), 174
} 
di dunia pengetahuan, selain terkenal di bidang tafsīr beliau juga seorang ahli fiqh. Hampir dari seluruh waktunya hanya difokuskan untuk mengembangkan bidang keilmuan, beliau adalah ulama yang hidup di abad ke-20 yang sejajar dengan tokoh-tokoh lainnya, seperti Thahir Ibnu Asyur, Said Hawwa, Sayyid Qutb, Muhammad Abu Zahrah, Mahmud syaltut, Ali Muhammad al-khafif, Abdul Ghani, Abdul Khaliq dan Muhammad Salam Madkur. ${ }^{11}$

Di bawah bimbingan orang tuanya, al-Zuhaili mengeyam pendidikan dasar-dasar agama Islam. Setelah itu, ia bersekolah di madrasah ibtida'iyyah di kampungnya, hingga jenjang pendidikan formal berikutnya. Gelar sarjana diraihnya pada tahun 1952 M, di Fakultas Syariah Universitas Damaskus, dan juga pendidikan Islam di Universiti al-Azhar, di mana ia sekali lagi menamatkannya dengan cemerlang pada tahun $1956 \mathrm{M}$. kemudian ia melanjutkan program magisternya di Universitas Kairo dan berhasil menamatkannya pada tahun 1959 M, serta meraih gelar doktor dalam bidang syar̄i'ah dari Universitas al-Azhar, Kairo pada tahun 1963 M. Wahbah al-Zuhaili kemudian mengabdikan diri sebagai dosen di almamaternya, Fakultas Syari'ah Universitas Damaskus, pada tahun 1963 M. Karir akademiknya terus menanjak, tak berapa lama, ia diangkat sebagai pembantu dekan pada Fakultas yang sama. Jabatan dekan sekaligus ketua jurusan Fiqh al-Is广ami juga digenggamnya dalam waktu relatif singkat dari masa pengangkatanya sebagai pembantu dekan. Selanjutnya, ia dilantik sebagai guru besar dalam disiplin hukum Islam pada salah satu universitas di Syiria. ${ }^{12}$

Wahbah al-Zuhaili yang terkenal ahli dalam bidang Fiqh dan Tafsir, serta berbagai disiplin ilmu lainnya, merupakan salah satu tokoh paling terkemuka di abad ke $20 \mathrm{M}$. Ia adalah ulama yang sejajar dengan tokoh-tokoh lainnya, seperti Tāāir Ibn Asyūr, Sa’ìd Hawwā, Sayyid Quṭb, Muhammad Abū Zahrah, Maḥmūd Shaltūt, dan lain-lain. Ia sendiri dibesarkan di lingkungan ulama-ulama Mazhab Hanafi, yang membentuk pemikirannya dalam mazhab fiqih. Walaupun bermazhab Hanafi, namun dalam pengembangan dakwahnya ia tidak mengedepankan mazhab atau aliran yang

${ }^{11}$ Lisa Rahayu, Makna Qaulan dalam al-Qur'an; Tinjauan Tafsir Tematik Menurut Wahbah al-Zuhaili ,( Skripsi Sarjana, Fakultas Ushuluddin Universitas UIN SUSKA Riau, Pekanbaru, 2010), 18.

${ }^{12}$ Saiful Amin Ghofur, Profil Para Mufasir al-Qur'an, 174. 
dianutnya. tetap bersikap netral ${ }^{13}$ dan proporsional ${ }^{14}$ dan senantiasa menghargai pendapat-pendapat mazhab lain. Hal ini, dapat dilihat dari bentuk penafsirannya ketika mengupas ayat-ayat yang berkaitan dengan fiqh. ${ }^{15}$

Dalam pekembangannya, ia tampil sebagai salah satu pakar perbandingan mazhab (muqaranàt al-madhähib). Salah satu magnum opus-nya, al-Fiqh al-Is $\left\lceil a m i \vec{i}\right.$ wa Adillatuhu. ${ }^{16}$ merupakan salah satu karya terakhir pada malam Sabtu, 8 Agustus 2015. Dunia Islam berdukacita karena kehilangan seorang ulama kontemporer panutan dunia. Wahbah al-Zuhaili berpulang ke Rahmatullah pada usia 83 tahun. ${ }^{17}$ fiqih komparatif yang popular di masa ini. Ia menghembuskan nafas

\section{Rezeki Dalam Interpretasi Wahbah Al-Zuhaili}

\section{QS. Hūd [11]:6 Dan Munasabahnya}

Allah SWT. menciptakan makhluk-Nya disesuaikan dengan kebutuhannya masing-masing. Terciptanya beragam makhluk di bumi ini serta terjaminnya rezeki yang merupakan kebutuhan dasar dalam keberlangsungan hidupnya menjadi tanda Kekuasaan-Nya. Setiap makhluk Allah yang ada di daratan, di laut maupun di udara semuanya ditanggung oleh Allah SWT. baik rezekinya, kebutuhan kehidupannya, serta makanan yang sesuai dengannya. Sehingga manusia di tuntut agar tidak mengkhawatirkan rezekinya dan juga tidak pesimis terhadap kurangnya pemenuhan kebutuhan hidupnya. ${ }^{18}$ Sebagaimana firman Allah SWT. dalam QS. Hūd [11]: 6

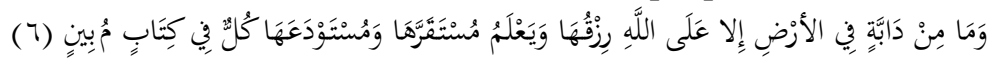

Dan tidak ada suatu binatang melata pun di bumi melainkan atas Allahlah rezekinya, dan Dia mengetahui tempat berdiamnya dan

\footnotetext{
${ }^{13}$ Tidak memihak.

${ }^{14}$ Keseimbangan.

15 Muhammad Ali Iyāzi, al-Mufasirūn Hayātuhum wa Manahajuhum (Teheran: Wizarah al-Tsaqāfah wa al-Insya' al-Islām, 1993), 684.

16 Wahbah al-Zuhaili, al-Fiqh al-IsTami wa Adillatuhū (Damaskus: Dār al-Fikr, 2011).

${ }^{17} \mathrm{http}: / / \mathrm{m}$. hidayatullah.com, Di akses pada hari Rabu 10 Juli 2019

18 Wahbah al-Zuhaili, Tafsir al-Munir: Aqidah, Syari'ah, Manhaj, Terj. Abdul Hayyie al-Kattani Dkk, Jilid 6, (Jakarta: Gema Insani, 2015), 209.
} 
tempat penyimpanannya. Semuanya tertulis dalam kitab yang nyata."(QS. Hūd [11]: 6). ${ }^{19}$

Dalam ayat ini, Allah menginformasikan kesempurnaan ilmuNya yang tiada suatu apapun yang tersembunyi dari-Nya. Bahkan Allah mengetahui apa yang ada di dalam kandungan, apakah laki-laki atau perempuan, satu ataukah lebih, bagus ataukah buruk sekalipun. ${ }^{20}$

\section{Munāsabah ayat}

Ayat sebelumnya berbicara tentang contoh perilaku orang yang buruk lagi bodoh, sebagian dari mereka menundukkan kepala mereka sehingga Rasulullah SAW tidak melihat mereka, dan sebagian yang lain berfikir bahwa mereka bisa menyembunyikan diri mereka dari Allah SWT. ini adalah puncak dari kebodohan. Meskipun mereka berusaha menutup rapat-rapat dengan apa yang ada pada diri mereka, maka tidak ada gunanya karena Allah mengetahui rahasiarahasia mereka baik yang ditampakkan ataupun yang disembunyikan dalam hati mereka. Dalam ayat sebelumnya terdapat kalimat Ya'lamu Mà Yusirrūna Wamā Yu'linūn yaitu Allah Mengetahui segala informasi, Maha Kuasa atas segala ciptaannya, Maha Memberi rezeki, Maha Mengetahui keadaan manusia, dan Dia yang membangkitkan setelah kematian. Maka kebangkitan itu adalah satu yang pasti terjadi dan tidak bisa dipungkiri. ${ }^{21}$ Pada ayat ini Allah menjelaskan kekuasaan-Nya yang Maha Mengetahui atas segala apa yang disembunyikan oleh hamba-Nya. Allah SWT. memberikan rezeki kepada hamba-Nya yang diketahui tempat berdiam serta tempat penyimpanan rezeki tersebut sekalipun tidak ada seorang pun yang mengetahuinya. Namun, Allah maha mengetahui atas segalanya. $^{22}$

\section{Interpretasi al-Qur'an Surah Hūd [11] ayat 6}

Salah satu bukti kekuasaan Allah SWT. yaitu menjamin terhadap semua makhluk-Nya atas rezeki dengan ketentuan yang nyata tanpa dikurangi maupun ditambah kecuali atas kehendaknya.

19 Kementerian Agama RI, al-Qur'an dan terjemahnya, (Jakarta: New Cordova, 2012), 222

${ }^{20}$ Wahbah al-Zuhaili, Tafsir al-Munïr: Aqidah, Syari'ah, Manhaj, Terj. Abdul Hayyie al-Kattani Dkk, Jilid 7, (Jakarta: Gema Insani, 2015), 123.

${ }^{21}$ Ibid, Jilid 6, 289.

${ }^{22}$ Ibid, Jilid 6, 289. 
Dalam menganalisa QS.Hūd [11] ayat ke 6,Wahbah al-Zuhaili memperinci ayat tersebut menjadi beberapa pembahasan.

(Wamā min dābbatin) Artinya dan tidak ada suatu binatang melata pun yaitu mencakup seluruh makhluk Allah di muka bumi ini. Dan huruf Min adalah huruf زئئد'idah) atau merupakan salah satu huruf tambahan dan kalimat الدابة (al-Dābbatu) dalam bahasa artinya setiap yang bergerak di atas bumi, baik yang merangkak dengan perutnya maupun berjalan dengan kakinya. ${ }^{23}$

Di samping itu, lafad الدابة (al-Dābbatu) sering dipahami dengan kuda, bighal, dan keledai. Ini adalah pemahaman secara istilah. $^{24}$

رزقها (rizquhā) artinya rezekinya, yaitu makanan dan kebutuhan hidupnya ${ }^{25}$, Allah yang akan menanggungnya sebagai karunia dan rahmat dari-Nya. Di sini disebutkan dengan lafaz wajib karena pasti sampainya dan terjamin dan sebuah paksaan untuk menyerahkan padanya. ${ }^{26}$

مستقر هistaqorrohā) tempat berdiam binatang di bumi. ${ }^{27}$ Artinya seluruh makhluk Allah diketahui tempat-tempat berdiamnya dimanapun tempatnya bahkan sampai ke suatu titik terkecil pun semuanya pasti diketahui oleh-Nya.

مستودعها (mustauda'ahā) tempat penyimpanannya yang dahulu masih tersimpan di dalamnya sebelum terlahir baik di dalam tulang sulbi atau Rahim ataupun telur, dan maksud dari tempat berdiam dan tempat penyimpanan adalah tempat-tempat kehidupan dan kematian atau tulang-tulang sulbi dan Rahim. ${ }^{28}$

(kullun fï kitābin mubïnin) maksudnya semua yang disebutkan tadi atau setiap binatang, baik keadaannya, rezekinya, tempat berdiamnya, atau tempat penyimpanannya semua terdata dan tertulis jelas di Lauh Mahfuz. ${ }^{29}$

Maksud ayat ini adalah Allah SWT. Maha Mengetahui segala sesuatu, dan Dia Maha Kuasa atas segala kemungkinan untuk

\footnotetext{
${ }^{23}$ Ibid, Jilid 6, 289.

${ }^{24}$ Ibid, Jilid 6, 289.

${ }^{25}$ Meliputi segala sesuatu yang dibutuhkan, baik yang berupa kebutuhan jasmaniah seperti makanan, pakaian, tempat tinggal dan lain-lain. Dan kebutuhan rohaniah seperti ilmu pengetahuan, kecerdasan, taufik serta hidayah dalam kehidupan.

${ }^{26}$ Ibid, Jilid 6, 289.

${ }^{27}$ Ibid, Jilid 6, 289.

${ }^{28}$ Ibid, Jilid 6, 289.

${ }^{29}$ Ibid, Jilid 6, 289.
} 
menyatakan tauhid dan apa yang telah disebutkan sebelumnya berupa janji kebaikan dan juga ancaman. ${ }^{30}$

Sejauh pengetahuan penulis, diantara beberapa tafsir karya Wahbah al-Zuhaili, metode yang digunakan yaitu menafsirkan ayatayat al-Qur'an secara global (umum), dan penafsirannya terlalu ringkas sehingga pemahaman penulis terhadap konteks ayat yang dikaji kurang sempurna. Oleh karenanya, hal tersebut menjadi salah satu kelemahan dari Tafsir al-Munir. Mengacu pada beberapa tafsir, baik mufassir dalam negeri khususnya maupun mufassir luar negeri pada umumnya banyak penulis temukan penafsiran secara detail, seperti Tafsir al-Misbāh karya M. Quraīsh Shihāb, Tafsir al-Qurtūbi $\bar{i}$ karya Syaīkh Imām al-Qurtūbi dan lain sebagainya.

M. Quraīsh Shihāb menafsirkan al-Qur'an perkata, beliau menguraikan kata demi kata, baik dari segi arti dan kedudukan kata tersebut, sehingga pemahaman penulis terhadap konteks tafsir tersebut hampir sempurna. Misalnya, dalam ayat yang sama seperti kata دابة (دäbbah) terambil dari kata (دب- ياب) dabba-yadubbu yang berarti bergerak dan merangkak. Ia biasa digunakan untuk binatang selain manusia, tetapi makna dasarnya dapat juga mencakup manusia. Memahaminya untuk ayat ini dalam arti umum lebih tepat. Pemilihan kata ini mengesankan bahwa rezeki yang dijamin Allah SWT. itu menuntut setiap dābbah untuk memfungsikan dirinya sebagaimana namanya, yakni bergerak dan merangkak, yakni tidak hanya tinggal diam menanti rezeki tetapi mereka harus bergerak, guna memperoleh rezeki yang disediakan Allah SWT. itu. ${ }^{31}$

Tafsìr al-Qurtūbỉ karya Syaīkh Imām al-Qurțūbi selanjutnya juga menjelaskan hal yang serupa dengan M. Quraīsh Shihāb secara detail yaitu penafsiran kata demi kata, baik kedudukannya serta arti dari kata yang ditafsirkan. Sebagai contoh, Syaīkh Imām al-Qurțūbi dalam menafsirkan QS. Hūd [11] ayat 6 mengambil kata pertama. Misalnya, وما من د/بة في الارض الا على الهه رزقها binatang melata pun di bumi melainkan Allah-lah yang memberi rezekinya". Huruf $L$ dalam ayat ini adalah huruf Nafi (huruf yang berfungsi meniadakan). Sedangkan huruf salah tambahan, dan دابة pada hakekatnya dibaca rafa' (dibaca dhammah), karena yang

\footnotetext{
${ }^{30}$ Ibid, Jilid 6, 289.

${ }^{31}$ M. Qurāish Shihāb, Tafsìr al-Misbāh: Pesan, Kesan dan Keserasian al-Qur'an, Vol. 6 (Jakarta: Lentera Hati, 2002), 193.
} 
dimaksud adalah وما دابة (wamā dābbatun) dan tidak ada suatu binatang. ${ }^{32}$

alam ayat ini berarti ملى huruf bermakna dari Allah rezekinya. Hal ini sebagaimana yang dibuktikan dari perkataan Mujahid, كل ما جاء من رزق فمن اله (kullu mā jā'a min rizqin faminallāh), "setiap rezeki datangnya dari Allah". Ada yang mengatakan, على اله adalah suatu keutamaan dan bukan kewajiban. Ada juga yang mengatakan, janji dari-Nya adalah benar. Penjelasan masalah ini telah dijelaskan sebelumnya dalam Surah al-Nisa'. رزقها dibaca rafa' karena menjadi mubtada'. Sedangkan menurut ulama kufah lafad tersebut dibaca rafa' karena menjadi sifat. Secara zahir, ayat ini umum namun maknanya khusus, karena kebanyakan dari binatang melata itu binasa sebelum diberi rezeki. ${ }^{33}$

\section{Konsep Rezeki Perspektif Wahbah al-Zuhaili}

Al-Zuhaili Dalam Tafsir al-Munïr tidak menjelaskan secara lengkap tentang pengertian rezeki seperti halnya Hamka. Hamka mendefinisikan rezeki yaitu pemberian atau karunia Allah yang diberikan kepada makhluk-Nya dan bisa bermanfaat bagi kehidupannya. $^{34}$ Diantara beberapa mufassir juga mendefinisikan sama persis dengan pendapat Hamka. Namun dalam ayat ini Wahbah hanya menguraikan tentang Jaminan rezeki terhadap seluruh makhluk Allah di bumi, di laut maupun di udara serta kebutuhan atas keberlangsungan hidup yang telah jelas dan tercatat di Lauhul Mahfü. ${ }^{35}$ maka, Jaminan rezeki ini merupakan rahmat dan karunia dari Allah SWT. serta menjadi bukti kebaikan-Nya terhadap ciptaanNya. $^{36}$

Berdasarkan uraian terhadap interpretasi QS. Hūd [11]: 6 dalam Tafsir al-Munïr maka peneliti dapat menemukan pandangan Wahbah al-Zuhaili tentang jaminan rezeki terhadap seluruh makhluk Allah dan dapat terkonsep sebagai berikut: Rezeki merupakan rahmat

32 Syāikh Imām al-Qurțubi, al-Jāmi' Li Ahkam al-Qur'an, terj. Ahmad Khatib dkk, Jilid 19, (Jakarta Selatan: Pustaka Azzam, 2009), 14.

${ }^{33}$ Ibid, 14.

34 Triyana Harsa, Taqdir Manusia Dalam Pandangan Hamka, (Banda Aceh: Pena, 2008), 69.

35 Wahbah al-Zuhaili, Tafsir al-Munir: Aqidah, Syari'ah, Manhaj, Terj. Abdul Hayyie al-Kattani Dkk, Jilid 6, (Jakarta: Gema Insani, 2015), 290.

${ }^{36}$ Wahbah al-Zuhaili, Tafsir al-Wajīz: al-Mausū'atul Qur'ānoyyatul Muyassarah, Terj. Tim Kuwais, (Jakarta: Gema Insani, 2007), 223. 
dan karunia dari Allah SWT. Manusia terjamin kesejahteraannya agar dapat berkembang biak serta dapat memperbaiki kehidupannya. Namun, meskipun rezeki manusia sudah dijamin oleh Allah, manusia masih mempunyai suatu kewajiban dalam mendapatkan rezeki yaitu berusaha dan bekerja sesuai kodrat manusia. ${ }^{37}$ Sebagaimana firman Allah dalam QS. al-Mulk [67] ayat ke 15.

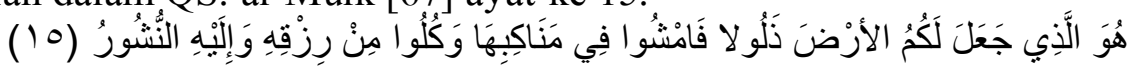
"Dialah yang menjadikan bumi untuk kamu yang mudah dijelajahi, maka jelajahilah di segala penjurunya dan makanlah sebagian dari rezeki-Nya. Dan hanya kepada-Nya lah kamu (kembali setelah) dibangkitkan".( QS. al-Mulk [67]: 15). ${ }^{38}$

Ayat ini menerangkan nikmat Allah yang tidak terhingga kepada manusia yang telah dilimpahkan kepadanya. Allah SWT. menyatakan bahwa Dia telah menciptakan bumi dan memudahkannya untuk mereka, sehingga mereka dapat mengambil manfaat yang tidak terhingga untuk kepentingan hidupnya. Selain dari itu, ayat ini juga menyatakan dengan sifat rahman-Nya kepada umat manusia, maka Allah bukan saja menyediakan seluruh sarana dan prasarana bagi manusia. Ia juga memudahkan manusia untuk hidup di permukaan bumi. Manusia diperintahkan untuk berjalan agar mengenali, baik tempatnya, penghuninya, manusianya, hewan dan tumbuhtumbuhannya. Manusia tidak saja diberi udara, tumbuh-tumbuhan, hewan dan cuaca yang menyenangkan, tetapi juga diberi perlengkapan dan kenyamanan untuk mencari rezeki (bekerja) di bumi dengan segala yang ada di atasnya maupun yang terkandung di dalamnya. ${ }^{39}$

Anjuran terhadap manusia untuk berusaha mencari rezeki dan kekayaan dalam hamparan bumi ini seperti mata air, tumbuhan dan kekayaan-kekayaan lainnya yang merupakan bagian dari rezeki Allah. Dengan demikian maksud dari jaminan rezeki bukan berarti manusia hanya menunggu datangnya rezeki tersebut tetapi jaminan tersebut akan terjamin jika dibarengi dengan usaha dan bekerja sebagaimana makna asal dari kata دابة (dabbah) yaitu bergerak dan merangkak. ${ }^{40}$

${ }^{37}$ Ibid,223.

38 Kementerian Agama RI, al-Qur'an dan terjemahnya, (Jakarta: New Cordova, 2012), 563

${ }^{39}$ Lajnah Pentashihan Mushaf al-Qur'an, Tafsir Tematik: Kerja dan Ketenagakerjaan, Jilid 2,(Jakarta: Aku Bisa, 2012), 37.

40 Wahbah al-Zuhaili, Tafsir al-Munir: Aqidah, Syari'ah, Manhaj, Terj. Abdul Hayyie al-Kattani Dkk, Jilid 6, (Jakarta: Gema Insani, 2015), 290. 
Dalam Tafsir al-Wasit, Wahbah al-Zuhaili juga menjelaskan hal yang serupa tentang jaminan rezeki. Beliau mengatakan, bahwasanya rezeki setiap makhluk-Nya akan terjamin dengan perantara sebab-akibat yang dalam hal ini beliau menganjurkan untuk berusaha dan bekerja. Salah satu contoh konkrit dari jaminan rezeki, ketika seseorang bekerja keras membanting tulang dari pagi hingga sore maka tidak menutup kemungkinan dengan perantara usahanya, orang tersebut akan mendapatkan rezeki itu maskipun sedikit. Wahbah juga mengatakan, bahwasanya seorang hamba dalam memperoleh rezeki tentu adanya campur tangan Allah yaitu ilham dan hidayah dalam pencariannya serta hasil yang dicari. ${ }^{41}$ Dalam hal ini Allah SWT. berfirman dalam surah Ṭ̂ohā [20]: 50.

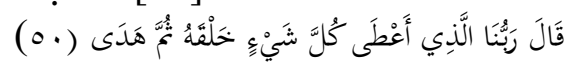

"Tuhan kami ialah (Tuhan) yang telah memberikan kepada tiap-tiap sesuatu bentuk kejadiannya, kemudian memberinya petunjuk". (QS. Ṭāhā [20]: 50).

Dalam interpretasinya Wahbah al-Zuhaili menyatakan bahwa setiap makhluk memiliki hak rezeki masing-masing atas kehendak Allah. Hamparan bumi ini menunjukkan kekuasaan Allah yang Maha Kuasa serta menjadi nikmat bagi seluruh penghuninya. Terjaminnya rezeki terhadap seluruh makhluk-Nya menjadi suatu bukti bahwasanya Allah menanggung kebutuhan ciptaannya. Lebih lanjut Wahbah al-Zuhaili menyatakan bahwa rezeki yang merupakan pemberian Allah dapat diperoleh dengan berusaha dan bekerja. Pernyataan pentingnya usaha dalam memperoleh rezeki diambil dari kata dābbah yang mempunyai arti bergerak dan merangkak. Bergerak dan merangkak adalah suatu upaya dalam memperoleh sesuatu yang diinginkan. Ketika seseorang berjalan menyusuri hamparan bumi, maka perjalanan tersebut merupakan satu upaya dalam sampainya tujuan tertentu.

Pembahasan Wahbah al-Zuhaili tentang rezeki dalam QS. Hūd [11]: 6 senada dengan pembahasan M. Quraish Shihab, beliau mengatakan bahwa Allah SWT. menjamin rezeki setiap makhluknya sebagai karunia dan dapat diperoleh dengan usaha dan bekerja. Adanya sarana yang dihiaskan kepada manusia menuntut dirinya sesuai namanya (dābbah) yaitu bergerak dan merangkak mencari

\footnotetext{
${ }^{41}$ Wahbah al-Zuhaili, Tafsìr al-Wasịt, (Damaskus: Dār al-Fikr, 2001), 1024.
} 
rezeki tersebut. ${ }^{42}$ Begitu juga dengan Imam al-Qurtubi dalam redaksinya menafsirkan ayat ini berlaku umum bagi seluruh makhlukNya tentang jaminan rezeki yang dengan rezeki tersebut bisa bertahan hidup setelah diawali dengan berusaha dan bekerja. Hal ini menunjukkan bahwasanya Allah tidak lalai untuk mendidik makhlukNya agar mengharap datangnya rezeki setelah melakukan usaha dan bekerja. $^{43}$

Dari paparan di atas menunjukkan kesamaan para mufassir dalam menyikapi jaminan rezeki. Kesamaan yang dimaksud mereka sama-sama memfokuskan pada kata dābbah yang dijadikan pangkal dari ayat tersebut yang mempunyai makna bergerak dan merangkak. Oleh karena itu, manusia dituntut untuk bergerak dengan berusaha dan bekerja agar memperoleh rezeki.

Dari penjelasan tentang jaminan rezeki di atas, perlu di jelaskan lebih luas lagi tentang macam-macam rezeki selain rezeki yang dijamin yang termaktub dalam al-Qur'an untuk memperjelas dan memperkuat hakikat rezeki secara terperinci sebagaimana berikut:

\section{Rezeki melalui Ikhtiār}

Termaktub dalam QS. al-Najm [53] ayat ke 39 yaitu manusia hanya akan memperoleh dari apa yang diusahakannya sendiri. Karena seberapa banyak usaha yang dilakukan, maka akan mendapatkan hasil sesuai yang diinginkan.

$$
\text { وَأَنْ لَيْنَ لِلإنْسَانِ إِلا مَا سَعَى (rq) }
$$

"Dan bahwa manusia hanya memperoleh apa yang telah diusahakannya". (QS. al-Najm [53]: 39). ${ }^{44}$

Seseorang tidak akan mendapatkan apa-apa melainkan ganjaran usahanya dan balasan amal perbuatannya. Oleh karena itu, seseorang tidak berhak mendapatkan ganjaran atas suatu amal yang tidak ia kerjakan. Ajaran terdahulu juga mengajarkan prinsip seperti

\footnotetext{
${ }^{42}$ M. Quraish Shihab, Tafsir al-Misbah: Pesan, Kesan dan Keserasian al-Qur'an, Vol. 6 (Jakarta: Lentera Hati, 2002), 193.

${ }^{43}$ Syaīkh Imam al-Qurtubi, al-Jāmi' Li Ahkam al-Qur'an, terj. Ahmad Khatib dkk, Jilid 19, (Jakarta Selatan: Pustaka Azzam, 2009), 15.

44 Kementerian Agama RI, al-Qur'an dan terjemahnya, (Jakarta: New Cordova, 2012), 527
} 
ini, sebagaimana seseorang tidak akan memikul pertanggung jawaban atau dosa dan kesalahan orang lain. ${ }^{45}$

Ayat di atas menjelaskan tentang balasan bagi orang yang berbuat dosa. Pada ayat sebelumnya, tiada seorang pun yang memikul dosa orang lain. Demikian juga sebaliknya, tiada pahala yang diperoleh bagi orang yang tidak mengerjakan amal kebaikan. Ayat ini lebih spesifik pada ganjaran amal yang diberikan di akhirat, sehingga dapat disimpulkan bahwa setiap sesuatu yang dikerjakan di dunia bisa saja mendapat balasan di dunia juga di akhirat. Salah satu contoh balasan di dunia seperti halnya rezeki yang akan di dapat oleh orang yang giat dalam bekerja. Kemudian di akhirat akan mendapatkan ganjaran atas apa yang dilakukan di dunia yaitu berusaha dan bekerja.

Dalam ayat yang lain, dijelaskan juga bahwa Allah akan melimpahkan karunia dan keadilan-Nya bahwa tidak ada hukuman tanpa kejahatan dan kesalahan. Sebagaimana firman Allah dalam QS. al-Ra'd [13]: 11.

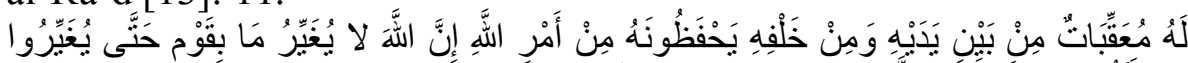

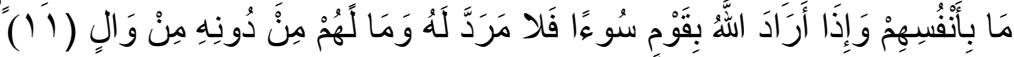
"Bagi manusia ada malaikat-malaikat yang selalu mengikutinya bergiliran, di muka dan di belakang, mereka menjaganya atas perintah Allah. Sesungguhnya Allah tidak merubah keadaan suatu kaum sehingga mereka merubah keadaan yang ada pada diri mereka sendiri. Dan apabila Allah menghendaki keburukan terhadap suatu kaum, maka tidak ada yang dapat menolaknya, dan sekali-kali tidak ada pelindung bagi mereka selain Dia”.(QS. Al-Ra'd [13]: 11).

Ayat di atas dapat di kiaskan dengan etos kerja dalam kehidupan dunia. Seseorang dapat memperoleh rezeki sesuai dengan usaha untuk mengubah hidupnya menjadi lebih baik dan limpahan rezeki yang banyak. ${ }^{46}$

2. Rezeki yang tiada disangka-sangka

Salah satu pekerjaan hati adalah Takwa. Takwa merupakan suatu upaya dalam memperoleh rezeki, sebagaimana Allah SWT. telah berfirman dalam QS.al-Ṭalāq [65]: 2-4.

${ }^{45}$ Wahbah al-Zuhaili, Tafsirir al-Munir: Aqidah, Syari'ah, Manhaj, Terj. Abdul Hayyie al-Kattani Dkk, Jilid 6, (Jakarta: Gema Insani, 2015),162.

${ }^{46}$ Wahbah al-Zuhaili, Tafsir al-Wajīz: al-Mausū'atul Qur'ānoyyatul Muyassarah, Terj. Tim Kuwais, (Jakarta: Gema Insani, 2007), 342. 


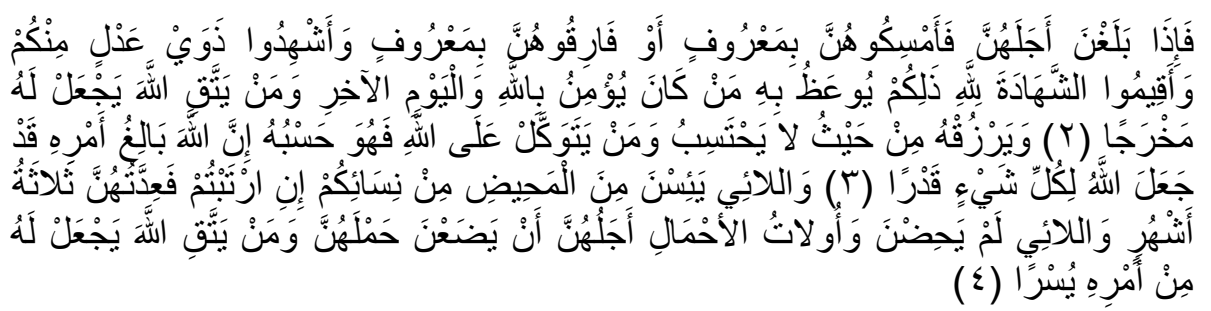

"Barang siapa bertaqwa kepada Allah niscaya Dia akan membukakan jalan keluar baginya, dan Dia memberinya rezeki dari arah yang tidak disangka-sangka, "Dan barang siapa bertawakkal kepada Allah, niscaya Allah akan mencukupkan (keperluan)nya. Sesunggunya Allah melaksanakan urusan-Nya. Sungguh, Allah telah mengadakan ketentuan bagi setiap sesuatu. Dan barangsiapa bertakwa kepada Allah, niscaya Dia menjadikan kemudahan baginya dalam urusannya". (QS. al-Talāq [65]: 2-4). ${ }^{47}$

Takwa adalah jalan keselamatan dari kebuntuan, situasi kritis, kesempitan, kesulitan, himpitan, kesusahan, dan kesedihan duniawi dan ukhrawi serta ketika mati. Urgensi dari takwa juga menjadi salah satu sebab datangnya rezeki yang baik, halal, dan luas yang tiada disangka-sangka dan diprediksikan. ${ }^{48}$

\section{Rezeki karena Istighfär}

Iman kepada Allah dapat menghimpun mereka dengan nikmat yang melimpah di akhirat serta kesuburan dan kekayaan di dunia. Ketika seseorang telah memantapkan hati untuk beriman kepada Allah SWT, maka yang terlintas dalam hatinya adalah suatu keyakinan bahwa pengharapan hanyalah kepada-Nya. Selain iman kepada Allah dapat melapangkan nikmat dunia maupun akhirat, Istighfar juga menjadi salah satu tangga dalam memperoleh rezeki dunia maupun akhirat. ${ }^{49}$ Sebagaimana cerita zaman Nabi Nūh yang kemudian difirmankan oleh Allah SWT dalam QS. Nūh [71]: 10-12.

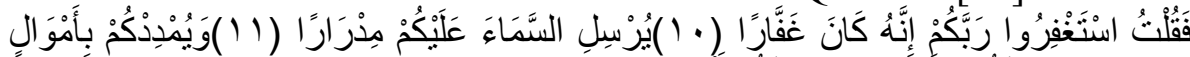

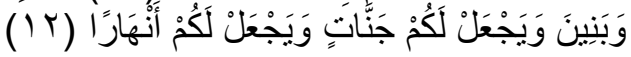

"Maka aku katakan kepada mereka, "Mohonlah ampun kepada Tuhanmu, sesungguhnya Dia adalah Maha Pengampun. Niscaya Dia

47 Kementerian Agama RI, al-Qur'an dan terjemahnya, (Jakarta: New Cordova, 2012),558.

${ }^{48}$ Wahbah al-Zuhaili, Tafsir al-Munir: Aqidah, Syari'ah, Manhaj, Terj. Abdul Hayyie al-Kattani Dkk, Jilid 14, (Jakarta: Gema Insani, 2015), 645.

${ }^{49}$ Ibid, Jilid 15, 157. 
akan mengirimkan hujan kepadamu dengan lebat. Dan membanyakkan harta dan anak-anakmu, dan mengadakan untukmu kebun-kebun dan mengadakan (pula di dalamnya) untukmu sungaisungai".(QS. Nūh [71]: 10-12).

Ayat di atas menyeru kepada kaum Nabi Nūh agar meminta ampunan kepada Allah dari segala kekufuran dan kemaksiatan dengan niat yang tulus, sehingga Allah SWT menurunkan hujan dari langit secara terus-menerus. Kemudian Allah memberi kenikmatan, kesuburan, hasil bumi, buah-buahan yang banyak serta kemakmuran, ketenangan, kebahagiaan dan kestabilan yang merata. Maka, di sini ada sebuah petunjuk bahwa Istighfar menyebabkan bertambahnya keberkahan dan pertumbuhan. Dengan demikian, ini adalah dalil bahwa kekuatan Istighfar dapat menurunkan hujan dan turunnya berbagai macam rezeki. ${ }^{50}$

\section{Rezeki karena bersyukur}

Syukur adalah ungkapan mengapresiasi nikmat disertai dengan memuliakan pihak yang memberi nikmat serta bertindak yang sesuai dan mencerminkan hal itu. ${ }^{51}$ Sesungguhnya mensyukuri nikmat dapat menambah nikmat, dan sikap kufur nikmat dapat mengurangi bahkan menghilangkan nikmat. Ayat di atas sangatlah jelas bahwa syukur menjadi sebab bertambahnya nikmat, dan kufur menjadi sebab kurangnya nikmat. Selain itu, terdapat hadits Rasulullah yang di riwayatkan oleh Bukhari dari Anas r.a. sebagaimana berikut: ${ }^{52}$

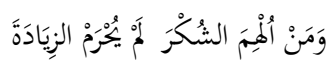

"Barangsiapa diberi ilham untuk bersyukur, ia tidak terhalang untuk mendapatkan tambahan".(HR. Bukhāri). Namun demikian, selain bersyukur menjadi salah satu jalan bertambahnya rezeki juga terdapat ancaman bagi yang tidak bersyukur. Ketika seseorang enggan untuk bersyukur maka dalam keadaan yang demikian orang tersebut disebut Kufur ${ }^{53}$ sebagaimana yang termaktub dalam QS. Ibrāhim [14]: 7.

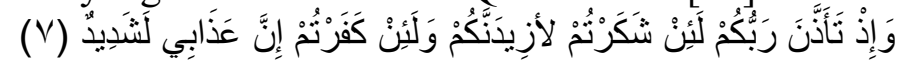

\footnotetext{
${ }^{50}$ Wahbah al-Zuhaili, Tafsìr al-Wasiț, (Damaskus: Dār al-Fikr, 2001), 2744.

${ }^{51}$ Wahbah al-Zuhaili, Tafsir al-Munir: Aqidah, Syari'ah, Manhaj, Terj. Abdul Hayyie al-Kattani Dkk, Jilid 7, (Jakarta: Gema Insani, 2015), 208.

${ }^{52}$ Ibid, Jilid 7, 206.

${ }^{53}$ Kufur disini bukanlah kafir terhadap ajaran agama Islam. Namun, Kufur terhadap Nikmat Allah SWT, artinya mengingkari adanya Nikmat Allah yang dilimpahkan kepadanya.
} 
"Dan (ingatlah) ketika Tuhanmu memaklumkan, "sesungguhnya jika kamu bersyukur, niscaya Aku akan menambah (nikmat) kepadamu, tetapi jika kamu mengingkari (nikmat-Ku), maka pasti azab-Ku sangat berat".(QS. Ibrāhim [14]: 7). ${ }^{54}$

5. Rezeki karena menikah

Pernikahan menjadi langkah terpeliharanya kesucian diri dari perbuatan zina serta terciptanya kebaikan dan kesalehan. Oleh sebab itu, pernikahan adalah jalan untuk menjaga diri dari perbuatan tercela dan amoral. ${ }^{55}$ Semua orang pasti berkeinginan untuk menambah kebaikan pada dirinya yang salah satunya dapat ditempuh dengan pernikahan. Disisi lain, pandangan manusia bisa saja pudar akibat perasaannya yang pesimis terhadap kecukupan biaya dalam menjalaninya. Allah SWT melarang sikap orang yang enggan menikah hanya karena alasan orang miskin. Justru Allah menjanjikan memberikan kecukupan kepada orang-orang yang menikah karena ingin menggapai Ridla-Nya dan menjaga diri dari perbuatanperbuatan kemaksiatan kepada-Nya. ${ }^{56}$ Sebagaimana firman Allah dalam al-Qur'an Surah al-Nūr [24]: 32.

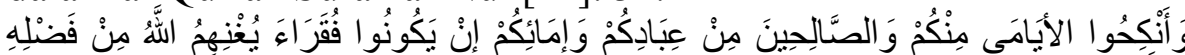

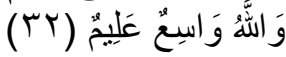
"Dan nikahkanlah orang-orang yang masih membujang diantara kamu, dan juga orang-orang yang layak (menikah) dari hamba-hamba sahayamu yang laki-laki dan perempuan. Jika mereka miskin, Allah akan memberi kemampuan kepada mereka dengan karunia-Nya. Dan Allah Maha Luas (pemberiannya), lagi Maha Mengetahui".(QS. alNūr [24]: 32). ${ }^{57}$

Ayat di atas adalah janji memberikan kecukupan bagi orang yang menikah. Selain ayat tersebut, Rasulullah SAW bersabda yang diriwayatkan oleh Ibnu Mājah dalam kitab sunannya dari Abi Hurairah r.a. Sesungguhnya Rasulullah SAW bersabda:

\footnotetext{
54 Kementerian Agama RI, al-Qur'an dan terjemahnya, (Jakarta: New Cordova, 2012), 256.

55 Wahbah al-Zuhaili, Tafsir al-Munir: Aqidah, Syari'ah, Manhaj, Terj. Abdul Hayyie al-Kattani Dkk, Jilid 9, (Jakarta: Gema Insani, 2015), 522.

${ }^{56}$ Ibid, 523.

${ }^{57}$ Kementerian Agama RI, al-Qur'an dan terjemahnya, (Jakarta: New Cordova, 2012), 354.
} 


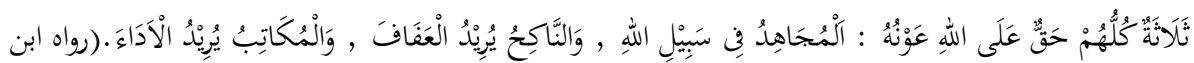

(a)

"Ada tiga orang yang Allah SWT pasti membantu mereka, yaitu orang yang berjuang di jalan Allah, orang yang menikah yang menginginkan untuk menjaga kesucian diri, dan budak mukatabah yang ingin membayar biaya kitabahnya".(HR. Ibnu Mājah). ${ }^{58}$

Adanya hadits di atas menjadi tolak ukur bagi seseorang yang belum menikah. Dengan demikian, hendaknya kita tetap optimis terhadap Kekuasaan Allah SWT bahwasanya orang yang menikah akan mendapatkan pertolongan Allah dan anjuran agar senantiasa mengharap Rahmat Allah SWT karena Allah-lah yang Maha Luas Kekayaan-Nya, demikian juga menciptakan manusia sekaligus menjamin atas rezeki-rezekinya. ${ }^{59}$

6. Rezeki karena sedekah

Sedekah disyari'atkan dengan tujuan untuk mengulurkan tangan kepada orang yang lemah, meminimalisir munculnya kecemburuan sosial, menjaga harta kekayaan orang yang kaya dari tindak pencurian, perampokan, perampasan dan pengrusakan. ${ }^{60}$ Allah Maha Kaya, Dia tidak butuh kepada sedekah para hamba-Nya. Dia Maha Kuasa memberi rezeki kepada siapapun yang dikehendaki-Nya. Keistimewaan sedekah juga menjadi jalan untuk menciptakan hubungan kasih sayang, memperkuat jalinan antar sesama, juga sebagai penguat perasaan simpati dan semangat saling membantu di antara sesama. ${ }^{61}$ Allah SWT berfirman dalam QS. al-Baqarah [2]: 245.

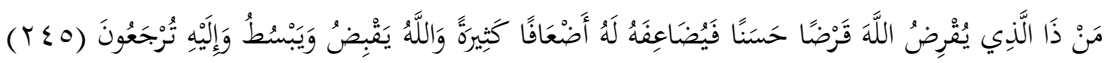
"Barangsiapa meminjami ${ }^{62}$ Allah dengan pinjaman yang baik maka Allah melipat gandakan ganti kepadanya dengan banyak. Allah

\footnotetext{
${ }^{58}$ Wahbah al-Zuhaili, Tafsìr al-Wasit, (Damaskus: Dār al-Fikr, 2001), 1749.

${ }^{59}$ Ibid, 1749.

${ }^{60}$ Wahbah al-Zuhaili, Tafsir al-Munir: Aqidah, Syari'ah, Manhaj, Terj. Abdul Hayyie al-Kattani Dkk, Jilid 2, (Jakarta: Gema Insani, 2015), 72.

${ }^{61}$ Ibid, Jilid 2, 72.

${ }^{62}$ Maksud meminjami Allah adalah menginfakkan dan menyedekahkan hartanya di jalan Allah.
} 
menahan dan melapangkan (rezeki) dan kepada-Nya lah kamu di kembalikan".(QS. al-Baqarah [2]: 245). ${ }^{63}$

\section{Rezeki karena anak}

Pada zaman dahulu, lahirnya seorang anak dianggap menjadi beban bagi orang tuanya dan khawatir terhadap minimnya rezeki untuk memenuhi kebutuhan hidup mereka. Mereka beranggapan bahwa semakin banyak anak, maka semakin kurang pemenuhan kebutuhan hidup sehingga mereka membunuh anak-anak mereka agar terhindar dari kemiskinan. Hal ini tergambar dalam firman Allah SWT QS. al-Isrā' [17]: 31.

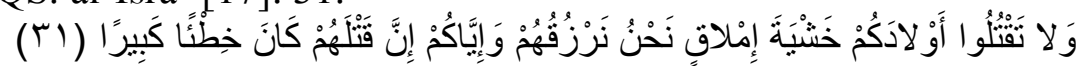

"Dan janganlah kamu membunuh anak-anakmu karena takut kemiskinan. Kamilah yang akan memberi rezeki kepada mereka dan juga kepadamu. Sesungguhnya membunuh mereka adalah suatu dosa yang besar". (QS. Al-Isrā' [17]: 31).

Ayat di atas dengan tegas melarang membunuh anak hanya karena takut miskin. Termasuk dosa besar yaitu membunuh anak dalam keadaan hidup-hidup. Selain itu, membunuh anak karena takut miskin adalah salah satu bentuk Sü'uzzan kepada Allah karena mendahulukan takdir Allah yang sudah jelas dan tegas bahwasanya semua makhluk-Nya ada jaminan rezeki masing-masing. Maka, seyogianya seorang hamba tidak mengkhawatirkan rezeki setiap anak yang dilahirkan, karena Allah yang menanggung rezeki anak-anak mereka bahkan rezeki mereka sendiri. ${ }^{64}$ Ayat di atas juga menunjukkan bahwa Allah SWT lebih menyayangi hamba-hambanya dibanding seorang ayah kepada anaknya sendiri. ${ }^{65}$

Di dalam Sahīh Bukhārì dan Muslim terdapat riwayat dari Ibnu mas'ūd, dia berkata:

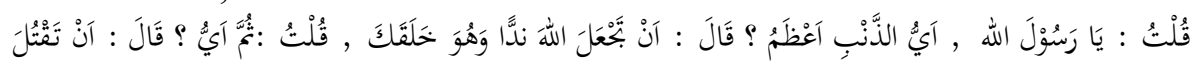

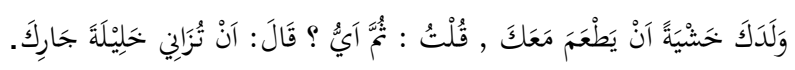

"Wahai Rasulullah, dosa apakah yang paling besar? Rasulullah menjawab: menjadikan sekutu bagi Allah, padahal Dia telah

\footnotetext{
${ }^{63}$ Kementerian Agama RI, al-Qur'an dan terjemahnya, (Jakarta: New Cordova, 2012), 39.

64 Wahbah al-Zuhaili, Tafsir al-Munir: Aqidah, Syari'ah, Manhaj, Terj. Abdul Hayyie al-Kattani Dkk, Jilid 8, (Jakarta: Gema Insani, 2015), 86.

${ }^{65}$ Wahbah al-Zuhaili, Tafsìr al-Wasit, (Damaskus: Dār al-Fikr, 2001), 1345.
} 
menciptakanmu. Kemudian saya bertanya lagi, "kemudian apa lagi?", Rasulullah menjawab," membunuh anakmu sendiri karena takut ia ikut makan denganmu. Kemudian saya bertanya lagi, "kemudian apa?", Beliau menjawab, "menzinahi istri tetangga". (HR. Bukhāri dan Muslim).

Berdasarkan analisis terhadap pemikiran Wahbah al-Zuhaili dapat dipahami bahwa pemikiran Wahbah al-Zuhaili dengan mufassir yang lain memiliki pandangan yang sama dalam mendeskripsikan Konsep Rezeki QS. Hūd [11]: 6. Wahbah al-Zuhaili secara detail menjelaskan bahwa jaminan rezeki dimiliki oleh seluruh makhlukNya, namun cara mendapatkan rezeki tersebut ada kerja keras dalam berusaha agar dapat mewujudkan jaminan rezeki tersebut. Di samping itu, berusaha dan bekerja merupakan suatu ibadah dalam rangka memenuhi perintah Allah SWT untuk mengubah nasib menjadi lebih baik.

Setelah menguraikan macam-macam rezeki dalam pandangan Wahbah al-Zuhaili, penulis dapat memahami bahwa rezeki bersifat netralitas dan dapat diperoleh dengan segala cara. Dalam QS. Hūd [11]: 6, Wahbah al-Zuhaili demikian juga mufassir-mufassir yang lain seperti M. Quraīsh Shihāb dan Syaīkh Imām al-Qurțūbi memiliki pandangan yang sama dalam menafsirkan ayat tersebut, semua makhluk Allah yang ada di bumi ini memperoleh rezekinya masingmasing melalui usaha dan bekerja yang di ambil dari pangkal ayat tersebut yaitu الدابة yang mempunyai arti bergerak dan merangkak. Di sini dapat dipahami bahwa manusia mempunyai suatu kewajiban dalam mencari rezeki karena telah dilengkapi dengan sarana prasarana yang aktif untuk dipergunakan dalam mencari apa yang diinginkan.

Disisi lain, banyak ayat yang juga menjelaskan tentang rezeki, rezeki juga dapat diperoleh dengan usaha tanpa harus bekerja keras. Jadi, setelah menganalisis QS. Hūd [11]: 6 dan ayat-ayat lain yang membahas tentang rezeki dapat dipahami bahwa rezeki setiap manusia ditanggung oleh Allah SWT yang sebagian dapat diperoleh dengan bekerja keras, sebagian lagi dapat diperoleh dengan usaha tanpa harus bekerja yang dikenal dengan amalan pembuka pintu rezeki. 


\section{Epilog}

Wahbah al-Zuhaili dalam penafsiranya terhadap QS. Hūd[11] ayat ke 6 mengatakan, bahwa Allah menanggung rezeki semua makhluk dan menjaminnya bagi mereka sebagai karunia dan rahmat dari Allah SWT. Ini merupakan dalil atas sifat-Nya yang Maha Adil dan Maha Pengasih, akan tetapi rezeki itu terikat dengan usaha dan bekerja untuk memperolehnya. Lebih lanjut Wahbah al-Zuhaili menegaskan bahwasanya rezeki dapat diperoleh dengan usaha dan bekerja. Namun, dalam ayat lain, Wahbah juga mengatakan bahwa rezeki dapat diperoleh dengan usaha tanpa harus bekerja yaitu dengan amalan-amalan memperoleh rezeki. Jadi, Wahbah al-Zuhaili memiliki pandangan bahwasanya rezeki ada yang dapat diperoleh melalui bekerja dan ada pula diperolehnya dengan usaha tanpa harus bekerja.

\section{Daftar Pustaka}

Abdullāh, Ali. Rumus Rezeki, Solo: Tiga Serangkai, 2017.

Agama, Kementerian.al-Qur'an dan terjemahnya, Jakarta: New Cordova, 2012.

Aliyudin, Mukhlis, Enjang AS, Mempercepat Datangnya Rezeki Dengan Ibadah Ringan, Bandung: Ruang Kata, 2012.

Azhar, Muhammad, Mudahnya Menjemput Rezeki yang Barokah, Solo: Assalam Publishing, 2014.

Azwar, Syaifuddin. Metode Penelitian, Yogyakarta: Pustaka Pelaja, 2012.

Bansiry (el), Mualimin. Tuntunan Hidup Kaya dengan Jalan Allah: Sikapdan Perilaku hidup yang Memudahkan Jalan Rezeki Anda, Yogyakarta: Luna Publisher, 2009.

Chalid, Abu Dawud. MetodologiPenelitian, Jakarta: BumiAksara, 1991.

Farmawi (al), Abdul Hayy, Metode Tafsir Maudhu'i dan cara penerapannya, terj. Rosihan Anwar dan Maman Abd Djaliel Bandung: PustakaSetia, 2002.

Ghofur, Syaiful Amin, Profil Para Mufassir al-Qur'an, Yogyakarta: Pustaka Insan Madani, 2008)

Gymnastiar, Abdullah, Menjemput Rezeki Dengan Berkah, (Jakarta: Republika, 2003.

Harsa, Triyana, Taqdir Manusia Dalam Pandangan Hamka, (Banda Aceh: Pena, 2008) 
Ibrahim, Ahmad Yasin, Meraih Rezeki Tak Terduga, Jakarta: Qultum Media,2006.

Iyāzi, Muhammad Ali, al-Mufasirūn Hayātuhum wa Manahajuhum Teheran: Wizarah al-Tsaqāfah wa al-Insya' al-Islām, 1993.

Kurniawan, Pasmadi Achmad, "Konsep Rezeki Dalam al-Qur'an" .Jurnal--STIT Muhammad Kendal, 2015.

M. Thomas, S. Nasution. Buku Penuntun Membuat Tesis Skripsi Disertasi Makalah, Jakarta: PT Bumi Aksara, 2011.

Mahfudz, Muhsin, Konstruksi Tafsir Abad 20 M/14 H; Kasus Tafsir al-Munir Karya Wahbah al-Zuhaili, Jurnal al-Fikr, vol. 14, no. 1, 2010.

Makhdlori Muhammad. Bacalah Surat al-Waqi'ah maka Engkau akan Kaya, Jokjakarta: DIVA pres, 2012.

Mubārok, Mufti, 9 Rahasia Pembuka Gembok Rezeki, Surabaya: Dinar Media, 2012.

Muhammad, Su'aib, Lima Pesan Al-Qur'an, Jilid 2, Malang: UinMaliki Press, 2011.

Muhyiddin Muhammad. Keajaiban Shodaqoh, Jokjakarta: DIVA pres, 2013.

Mulya, Risdian. Jangan Mati Sebelum Kaya, Jokjakarta: DIVA pres, 2013.

Mu'is, Fahrur, Dikejar Rezeki dari Sedekah, Solo: Taqiya Publishing, 2016

Moleong, Lexy J. Metodologi Penelitian Kualitatif, Bandung: PT Remaja Rosda karya, 2007.

Nurrohiem, Insan, Kaya itu Bonus, (Yogyakarta: Laksana, 2018)

Qurtubi (al), Abu Abdallah, Al-Jami' Li Ahkam al-Qur'an, Juz II Beirut: Dar al-Fikr, 1994.

Qurtubi (al), Syaīkh Imā̄, al-Jāmi' Li Ahkam al-Qur'an, terj. Ahmad Khatibdkk, Jilid 19, (Jakarta Selatan: PustakaAzzam, 2009)

Qur'an (al), Lajnah Pentashihan Mushaf, Tafsir Tematik: Kerjadan Ketenaga kerjaan, Jilid2, Jakarta: AkuBisa, 2012.

Rahayu, Lisa, Makna Qaulan dalam al-Qur'an; Tinjauan Tafsir Tematik Menurut Wahbah al-Zuhaili ,SkripsiSarjana, FakultasUshuluddinUniversitas UIN SUSKA Riau, Pekanbaru, 2010.

Rahman, Afzalur, DoktrinEkonomi Islam, (Yogyakarta: Dana Bhakti Wakaf, 1995) 
Sakandari (al), Ibnu Ața'illah, Agar Rezeki yang MencarimuBukankau yang Mencarinya, Jakarta: Zaman, 2014.

Saleh, AkhMuwafik, Bekerja dengan Hati Nurani, Penerbit Erlangga, 2009.

Sha'rawi (al),Syaīkh Muhammad Mutawalli, Itulah Rezeki: Kupas Tuntas Hakikat Rezeki, ter. EkaNurdiana, Shofw El-Fikry Media, 2016.

Shihāb, M Quraīsh, Menyingkap Tabir Ilahi, Jakarta: Lentera Hati, 2005.

Shihāb M. Quraīsh.Tafsir al-Misbāh: Pesan, Kesan, dan Keserasian al-Qur'an, Vol. 6, Jakarta: Lentera Hati, 2002.

Shihāb, M. Quraīsh, Wawasan al-Qur'an: Tafsir Tematik Atas Berbagai Persoalan Umat, Bandung: Mizan Pustaka, 2007.

Sunggono, Bambang. Metodologi Penelitian Hukum, Jakarta: PT Raja Grafindo, 2007.

Tanzeh, Ahmad. Pengantar Metode Penelitian, Yogyakarta: Teras, 2009.

Usman M. Ali. Rezeki dalam al-Qur'an, Bandung: PT KiblatBukuUtama, 2010.

Zein, Syauqi Abdillah, Jurus-Jurus Langit Pengguyur Rezeki, Yogyakarta: Laksana, 2018.

Zuhaili (al), Wahbah, al-Fiqh al-Is「amìiwa Adillatuhü, Damaskus: Dār al-Fikr, 2011.

Zuhaili (al), Wahbah,, Tafsir al-Munï: Aqidah, Syari'ah, Manhaj, Terj. Abdul Hayyie al-Kattani Dkk, Jilid 11, Jakarta: Gema Insani, 2015.

Zuhaili (al), Wahbah, Tafsir al-Wajīz: al-Mausū'atul Qur'ānoyyatul Muyassarah, Terj. Tim Kuwais, Jakarta: GemaInsani, 2007.

Zuhaili (al), Wahbah, Tafsìr al-Wasit, Damaskus: Dār al-Fikr, 2001. 